CAROLINO, Katia; STANZIOLA VIEIRA, Ricardo; SORRENTINO, Marcos. Land dilemmas in brazil: the history of land privatization in Brazil. Revista Eletrônica Direito e Política, Programa de Pós-Graduação Stricto Sensu em Ciência Jurídica da UNIVALI, Itajaí, v.16, n.2, 20 quadrimestre de 2021. Disponível em: www.univali.br/direitoepolitica - ISSN 1980-7791.

\title{
LAND DILEMMAS IN BRAZIL: THE HISTORY OF LAND PRIVATIZATION IN
} BRAZIL ${ }^{1}$

\author{
DILEMAS DE TERRAS NO BRASIL: A HISTÓRIA DA PRIVATIZAÇÃO DE TERRAS \\ NO BRASIL
}

\author{
Katia Carolino ${ }^{2}$ \\ Ricardo Stanziola Vieira ${ }^{3}$ \\ Marcos Sorrentino ${ }^{4}$
}

\begin{abstract}
This article aims to present, from a historical perspective, the main legal instruments on access to land, based on authors who have studied the agrarian issue in Brazil, namely: João Pedro Stédile (2011), José de Souza Martins (1980), Marcia Maria Mendes Motta (1998), Maria Ligia Osório Silva (1996, 1997), Ruy Cirne Lima (1954), among others. It also aims to demonstrate how legislation has advanced in the process of recognizing the socio-environmental function of property while it brought ambiguities that have led to regression in terms of a fairer and more equitable distribution of land, essential to human needs, such as housing and food. The materials used to prepare the article came from primary and secondary sources collected through bibliographic and documentary research.
\end{abstract}

KEYWORDS: property of land, socio-environmental function of property, Brazilian legislation.

\section{RESUMO}

Este artigo tem como objetivo apresentar, numa perspectiva histórica, os principais instrumentos jurídicos sobre o acesso à terra, a partir de autores que estudaram a questão agrária no Brasil, a saber: João Pedro Stédile (2011), José de Souza Martins (1980), Marcia Maria Mendes Motta (1998), Maria Ligia Osório

\footnotetext{
1 We are grateful to the Queen Elizabeth Scholars program, funded by the Canadian Council for Research in Social and Human Sciences and the Development Research Center and the Coordination for the Improvement of Higher Education Personnel in Brazil for the doctoral scholarship granted to Katia Carolino.

$2 \mathrm{PhD}$ in Environmental Science and researcher at the Laboratory of Education and Environmental Policy (Oca) at the Luiz de Queiroz Higher School of Agriculture at the University of São Paulo (Brazil) and in the Ecological Economy, Commons Governance and Climate Justice project at York University. Email: carolino.ea@gmail.com.

3 Postdoctoral position at the Center for Interdisciplinary Research in Environmental Law, Urban Planning and Territorial Management (Crideau, University of Limoges - France). Professor in the Master and Doctorate Courses of the Stricto Sensu Postgraduate Program in Legal Science and in the Master Course in Public Policy Management - UNIVALI. E-mail: stanziolaricardo@gmail.com.

4 Senior professor in the Department of Forest Sciences and coordinator of the Laboratory of Education and Environmental Policy (Oca), both at the Luiz de Queiroz Higher School of Agriculture at the University of São Paulo (Brazil). E-mail: sorrentino.ea@gmail.com.
} 
CAROLINO, Katia; STANZIOLA VIEIRA, Ricardo; SORRENTINO, Marcos. Land dilemmas in brazil: the history of land privatization in Brazil. Revista Eletrônica Direito e Política, Programa de Pós-Graduação Stricto Sensu em Ciência Jurídica da UNIVALI, Itajaí, v.16, n.2, $2^{\circ}$ quadrimestre de 2021. Disponível em: www.univali.br/direitoepolitica - ISSN 1980-7791.

Silva (1996, 1997), Ruy Cirne Lima (1954), entre outros. Também visa demonstrar como a legislação avançou no processo de reconhecimento da função socioambiental da propriedade ao mesmo tempo em que trouxe ambiguidades que têm levado a um retrocesso em termos de uma distribuição mais justa e equitativa de terras, essenciais às necessidades humanas, como a habitação e comida. Os materiais utilizados na elaboração do artigo foram provenientes de fontes primárias e secundárias coletadas por meio de pesquisas bibliográficas e documentais.

PALAVRAS-CHAVE: propriedade da terra, função socioambiental da propriedade, legislação brasileira.

\section{INTRODUCTION}

Since the Brazilian colonization, with the first laws implemented by the Portuguese Crown, later with the Land Law of 1850, the Land Statute of 1964 and the Federal Constitutions, especially the one enacted in 1988, significant advances have occurred in terms of the creation of legal instruments with the aim of regulating access to land.

Although full property of land has been limited by legal institutes such as expropriation, usucapion and, subsequently, by socio-environmental function of property, they have not been able to alter the unequal relations existing in Brazilian society, breaking with the superiority of private interest, created based on the liberal tradition of law, which precludes any social interpretation of legal norms.

In this context, this article aims to present, from a historical perspective, the main legal instruments on with access to land based on authors who have studied the agrarian issue in Brazil, namely: João Pedro Stedile ${ }^{5}$, José de Souza Martins ${ }^{6}$,

${ }^{5}$ STEDILE, J. P. The agrarian issue in Brazil. The traditional debate - 1500-1960. 2nd edition. Editora Expressão Popular, São Paulo, 2011.

${ }^{6}$ MARTINS, J. de S. Expropriation and violence (The political issue in the field). São Paulo, Hucitec, 1980. 
CAROLINO, Katia; STANZIOLA VIEIRA, Ricardo; SORRENTINO, Marcos. Land dilemmas in brazil: the history of land privatization in Brazil. Revista Eletrônica Direito e Política, Programa de Pós-Graduação Stricto Sensu em Ciência Jurídica da UNIVALI, Itajaí, v.16, n.2, $2^{\circ}$ quadrimestre de 2021. Disponível em: www.univali.br/direitoepolitica - ISSN 1980-7791.

Marcia Maria Menendes Motta7, Maria Ligia Osório Silva ${ }^{8}$, Ruy Cirne Lima ${ }^{9}$, among others. It also aims to demonstrate how legislation has advanced in the process of recognizing the socio-environmental function of property while it brought ambiguities that have led to regression in terms of a fairer and more equitable distribution of land, essential to human needs, such as housing and food.

\section{METHODOLOGICAL PATH}

The materials used to prepare the article came from primary and secondary sources collected through bibliographic and documentary research. Secondary sources are "the search for second-hand data, that is, information that has already been worked on by other researchers, scholars and, therefore, is already in the scientific domain". While the primary sources are the "original data, from which the researcher has a direct relationship with the facts to be analyzed, that is, he is the one who analyzes, observes, for example, $(. .$.$) ; it is he who hears the report$ of experiences lived by others" ${ }^{10}$.

Within the scope of this research, the secondary sources include, for example, books, scientific articles, dissertations and theses, while the primary sources comprise the official documents (laws, decrees, ordinances, among other normative acts) related to the history of land legislation.

Secondary data were collected through bibliographic research that "is a modality of study and analysis of scientific documents" whose main purpose is "to lead the researcher to come into direct contact with works, articles or documents on the topic under study". While the primary data were obtained through documentary research that "is characterized by the search for information in documents that have not received any scientific treatment"11.

\footnotetext{
7 MOTTA, M. M. M. At the Frontiers of Power: land conflict and land rights in 19th century Brazil. Public Archives of the State of Rio de Janeiro, Rio de Janeiro, 1998.

8 SILVA, L. M. O. Devoluted Lands and Latifundio. Effects of the 1850 law. Editora da Unicamp. Campinas, 1996; SILVA, L. M. O. Agrarian Laws and the Unproductive Latifundio. São Paulo In Perspective, v. 11, n. 2, Sao Paulo, April - June 1997.

9 LIMA, R. C. Small territorial history of Brazil: "sesmarias" and vacant lands. Imprenta, Porto Alegre, Sulina, 1954.

10 OLIVEIRA, M. M. de. How to do qualitative research. Publisher Vozes, Petrópolis, 2007, p. 70.

11 OLIVEIRA, M. M. de. How to do qualitative research, p. 69.
} 
CAROLINO, Katia; STANZIOLA VIEIRA, Ricardo; SORRENTINO, Marcos. Land dilemmas in brazil: the history of land privatization in Brazil. Revista Eletrônica Direito e Política, Programa de Pós-Graduação Stricto Sensu em Ciência Jurídica da UNIVALI, Itajaí, v.16, n.2, $2^{\circ}$ quadrimestre de 2021. Disponível em: www.univali.br/direitoepolitica - ISSN 1980-7791.

\section{AGRARIAN LEGISLATION AND POLICY}

In reference to the studies of Darcy Ribeiro gathered in the book "The Brazilian People", João Pedro Stédile ${ }^{12}$ states that when European colonists invaded Brazilian territory there were approximately 5 million people, distributed in more than 300 tribal groups, organized in social groups of 100 to 500 families, basically living on hunting, fishing and fruit extraction. According to the author, at that time, a concept of property did not yet exist, since "all the natural elements existing in the territory - land, water, rivers, fauna, flora - were all, of possession and collective use and were used with the sole purpose of meeting the social needs of groups survival", in such a way that "when natural elements became scarce in certain regions, the groups moved to other places, which characterized their condition of nomadic living".

From 1500, with the arrival of the Portuguese to the Brazilian territory, indigenous peoples were subjected to the political will of the Portuguese Monarchy and to guarantee the possession in the new territory and prevent invasion by other interested, rules were created that allowed the occupation of Brazilian lands by the Portuguese. The Brazilian territory, from 1530, was then divided into 15 huge strips of land, from the coast to the imaginary line of Tordesillas, known as Hereditary Captaincies, which, in turn, came to be administered by people linked to the Kingdom from Portugal - the so-called "donatários" - by donation letters.

With almost absolute power over the Hereditary Captaincies, the "donatários" had autonomy to divide the lands into several parts - the so-called "sesmarias" donating them to anyone who could manage them, building the necessary infrastructure such as mill, slave quarters, among others. While the "sesmeiros" had to make a series of commitments, especially the full use of the donated land, often unrealizable due to the large size of the land granted $^{13}$.

\footnotetext{
12 STEDILE, J. P. The agrarian issue in Brazil. The traditional debate 1500-1960. p. 18-19.

13 TALASKA, A. The Brazilian agrarian space from a conceptual perspective: from legal aspects to territorial implications. Thesis (Doctorate in Regional Development) - University of Santa Cruz do Sul, Santa Cruz do Sul, 2015.
} 
CAROLINO, Katia; STANZIOLA VIEIRA, Ricardo; SORRENTINO, Marcos. Land dilemmas in brazil: the history of land privatization in Brazil. Revista Eletrônica Direito e Política, Programa de Pós-Graduação Stricto Sensu em Ciência Jurídica da UNIVALI, Itajaí, v.16, n.2, $2^{\circ}$ quadrimestre de 2021. Disponível em: www.univali.br/direitoepolitica - ISSN 1980-7791.

Thus, contrary to what happened in Portugal, in which the "sesmarias" concession was created to solve the food supply problem that occurred at the end of the 14th century, in Brazil, the "sesmarias" concession aimed at the colonization of Brazilian lands ${ }^{14}$.

Although the original concern with the productive and continuous use of the land has been maintained, the "sesmarias" in Brazil made possible the formation of country estate, existing until today, since, in addition to the concession of extensive areas of land by the Portuguese Crown, "sesmeiros", over time, also occupied other areas of land. The final text of the License of October 5, 1795 demonstrates this situation when the Queen, through measurements and demarcations of the lands granted to "sesmeiros", tried to regulate the abuses committed by the "sesmeiros".

License, in which Your Majesty, disapproving and correcting the abuses, irregularities and disorders, which has given rise to the lack of the Regiment of the "sesmarias" of the State of Brazil, is served to order a firm and unavoidable form of its dates, confirmations and demarcations: giving them invariable rules to process the causes of these "sesmarias" with other equally useful measures to the end. Everything as stated above ${ }^{15}$.

Marcia Maria Menendes Motta ${ }^{16}$ explains that, even after the issuance of the License of October 5, 1795, the owners continued to disregard the measurement and demarcation of land. According to the author, "measuring and demarcating, following the requirements of the legislation on "sesmarias", meant, for "sesmeiros", to submit to the imposition of a limit to their territorial expansion, to subjugate themselves - in these cases - to the general interests of a Crown so far". In addition, territorial expansion did not refer only to the question of the physical limits of the owners or the capacity for economic growth of an extensive culture, it also meant the possibility of obtaining dominion over the men who lived there or wished to live there. For the author:

${ }^{14}$ MOTTA, M. M. M. At the Frontiers of Power: land conflict and land rights in 19th century Brazil.

15 BRASIL. License of October 5, 1795, Rio de Janeiro, RJ, 1795.

${ }^{16}$ MOTTA, M. M. M. At the Frontiers of Power: land conflict and land rights in 19th century Brazil. p. 38. 
CAROLINO, Katia; STANZIOLA VIEIRA, Ricardo; SORRENTINO, Marcos. Land dilemmas in brazil: the history of land privatization in Brazil. Revista Eletrônica Direito e Política, Programa de Pós-Graduação Stricto Sensu em Ciência Jurídica da UNIVALI, Itajaí, v.16, n.2, $2^{\circ}$ quadrimestre de 2021. Disponível em: www.univali.br/direitoepolitica - ISSN 1980-7791.

$(\ldots), \quad$ [the "sesmeiros"] resisted in measuring and demarcating their lands because such territorial limitation implied a limit to the exercise of their power over neighbors and possessor and a subordination to external power, represented by the Crown. Being lord of lands meant, first, being lord - and it was above all this manorial domain that could not be measured or limited ${ }^{17}$.

In this context, Ligia Maria Osório Silva explains that:

Despite the conditionality of the donation, the metropolis, while the "sesmarias" concession regime lasted, never managed to prevent the formation of unproductive land property. In addition to that used effectively in a productive way in plantations, great stretches of land were appropriated, now to guarantee future explorations, featuring a large-scale migratory culture, now as a store of value ${ }^{18}$.

Therefore, during the colonial period, in addition to the "sesmarias", little by little, another legal category - the possession - received the recognition from the Portuguese authorities ${ }^{19}$. As a result, through the Resolutions of April 11 and August 2, 1753, it was determined that "the lands given in "sesmarias" where there were colonists cultivating the soil and paying forum to the "sesmeiros" should be given to the reals cultivators" 20 .

According to José de Souza Martins ${ }^{21}$, as the "sesmarias" concession was given only to those who met the conditions imposed by the Portuguese Crown, people with few material resources became the first possessors in disagreement with the rules imposed by Portugal. These possessors occupied land until then not used by "sesmeiros", sometimes distant from the population centers.

Thus, during the colonial period, possession also represented the form of occupation of the small farmer who was unable to request a "sesmaria", developing, therefore, on the margins of latifundios. However, due to the power that the "sesmeiros" already held over the land, the possession also took on the shape of latifundios, since "the same conditions that led to the lack of control over

\footnotetext{
17 MOTTA, M. M. M. At the Frontiers of Power: land conflict and land rights in 19th century Brazil. p. 39.

${ }^{18}$ SILVA, L. M. O. Agrarian Laws and the Unproductive Latifundio. p. 16.

19 SILVA, L. M. O.; SECRETO, M. V. Public lands, private occupation: elements for the comparative history of territorial appropriation in Argentina and Brazil. Economy and Society, v. 8 n. 1, Campinas, December 1999. p. 115.

20 MOTTA, M. M. M. At the Frontiers of Power: land conflict and land rights in 19th century Brazil. p. 123.

${ }^{21}$ MARTINS, J. de S. Expropriation and violence (The political issue in the field). São Paulo, Hucitec, 1980.
} 
CAROLINO, Katia; STANZIOLA VIEIRA, Ricardo; SORRENTINO, Marcos. Land dilemmas in brazil: the history of land privatization in Brazil. Revista Eletrônica Direito e Política, Programa de Pós-Graduação Stricto Sensu em Ciência Jurídica da UNIVALI, Itajaí, v.16, n.2, 20 quadrimestre de 2021. Disponível em: www.univali.br/direitoepolitica - ISSN 1980-7791.

the size of the "sesmarias" caused the possession limit to be given by the possessor himself"22.

Due to the disputes between "sesmeiros" and possessors, and between these and the colonial authorities, the maintenance of the "sesmarias" concession in Brazil has become unsustainable. With Resolution no 76, of July 17,1822 , by Prince Regent D. Pedro, the concession of "sesmarias" was suspended, consecrating the possession institute ${ }^{23}$. The possession became, then, "the only form of acquisition of domain of the lands, even if only in fact, and, for this reason, in the history of territorial appropriation, this period became known as the 'golden phase of the squatter'"24.

With the promulgation of the first Brazilian Federal Constitution, on March 25, $1824^{25}$, elaborated under the influence of the Napoleon Code of 1804 which, in turn, encouraged liberal individualism, the right of property ${ }^{26}$ was fully guaranteed 27 . This Constitution did not regulate the "sesmarias", nor the possessions. The property right was limited only by the legal institute of expropriation ${ }^{28}$, later regulated by ordinary law that distinguished cases of expropriation due to public necessity and utility ${ }^{29}$.

In 1850, the first agrarian legislation was drafted - Law no 601 of September 18, $1850^{30}$, known as the Land Law - that regulated the vacant lands of the Empire, later complemented by Decree no 1318 , of January $30,1854^{31}$.

22 SILVA, L. M. O. Agrarian Laws and the Unproductive Latifundio. São Paulo In Perspective, v. 11, n. 2, Sao Paulo, April - June 1997. p. 16.

23 With the end of the "sesmarias" concession, the Brazilian territory was, until 1850, without specific legislation to regulate access to land.

24 SILVA, L. M. O.; SECRETO, M. V. Public lands, private occupation: elements for the comparative history of territorial appropriation in Argentina and Brazil. Economy and Society, v. 8 n. 1 , Campinas, December 1999. p. 117.

25 BRASIL. Political Constitution of the Empire of Brazil (March 25, 1824). Rio de Janeiro, RJ, 1824.

26 The property right is one of the oldest prerogatives of mankind and its concept has been modified and evolved with the change of social and historical conditions (DEBONI, 2010). On the historical origin of private property and its development in Classical Antiquity, specifically in Roman Law, passing through the Middle Ages (Feudal Law), Modern Age (French Revolution), until the Contemporary Age, see the work of Giuliano Deboni (2010).

27 Article 179, item XXII, of the Brazilian Federal Constitution of 1824

28 Article 179, item XXII, of the Brazilian Federal Constitution of 1824.

29 VIEIRA, J. C. Constitutional aspects of Agrarian Law - Constitutional Amendment no 10/64, Semina: Cultural and Scientific Magazine of the State University of Londrina, v. 9, n. 1, Londrina, September 1988.

30 BRASIL. Law n' 601, September 18, 1850. Provides for the vacant lands of the Empire. Rio de Janeiro, RJ, 1850.

${ }^{31}$ BRASIL. Decree no $\mathbf{1 . 3 1 8}$, of January 30, 1854. It orders to execute Law no 601 , of September 18, 1850. Rio de Janeiro, RJ, 1854. 
CAROLINO, Katia; STANZIOLA VIEIRA, Ricardo; SORRENTINO, Marcos. Land dilemmas in brazil: the history of land privatization in Brazil. Revista Eletrônica Direito e Política, Programa de Pós-Graduação Stricto Sensu em Ciência Jurídica da UNIVALI, Itajaí, v.16, n.2, $2^{\circ}$ quadrimestre de 2021. Disponível em: www.univali.br/direitoepolitica - ISSN 1980-7791.

Among the main points of this law, $\operatorname{Motta}^{32}$ (1998, page 141 - 142) points out that: 1 ) the purchase was the only legal form of acquisition of vacant land; 2) vacant lands would be defined by excluding private lands; 3 ) there would be a reserve of vacant land for the purposes of colonization, settlement foundation, opening of roads, shipbuilding; 4) the "sesmarias" and the meek and peaceful possession of the first occupants would be revalidated, if they were cultivated or with agricultural culture in early stage; 5) land acquired through possessions, "sesmarias" or other concessions should be demarcated within a period to be stipulated; 6) the possessor who failed to carry out the measurement would have their land collapsed in commission, keeping only the possession of the cultivated land; 7) the obligation of the possessors to acquire title to their land; 8) and the organization of the parish registration of owned land.

This law, therefore, represented an attempt by the Imperial State to regain control of vacant land due to the appropriation process that occurred in the previous period. To that end, the Land Law determined that the procedure for identifying would be done by excluding what was not private land. According to Motta ${ }^{33}$, it was a reverse procedure, since it started from the survey of private lands to identify public lands by exclusion. According to the Land Law:

Article 3. The following are vacant lands:

$\S 10$ Those that are not applied to any national, provincial, or municipal public use.

$\S 20$ - Those that are not in the private domain by any legitimate title, nor are held by "sesmarias" and other concessions of the General or Provincial Government, not incurred in commission for failure to comply with the conditions of measurement, confirmation and culture.

$\S 30$ - Those that are not given by "sesmarias", or other concessions from the Government, which, despite incursions in "comisso", are revalidated by this Law.

$\S 40$ - Those that are not occupied by possessions, which, despite not being founded in a legal title, are legitimized by this Law ${ }^{34}$.

The Land Law determined that land granted by the "sesmarias" or possession would not be considered vacant land if it were regularized, in such a way that the

\footnotetext{
32 MOTTA, M. M. M. At the Frontiers of Power: land conflict and land rights in 19th century Brazil. p. $141-142$.

${ }_{33}$ MOTTA, M. M. M. At the Frontiers of Power: land conflict and land rights in 19th century Brazil.

${ }^{34}$ BRASIL. Law $\mathbf{n}^{\circ} \mathbf{6 0 1}$, September 18, 1850. Provides for the vacant lands of the Empire. Rio de Janeiro, RJ, 1850.
} 
CAROLINO, Katia; STANZIOLA VIEIRA, Ricardo; SORRENTINO, Marcos. Land dilemmas in brazil: the history of land privatization in Brazil. Revista Eletrônica Direito e Política, Programa de Pós-Graduação Stricto Sensu em Ciência Jurídica da UNIVALI, Itajaí, v.16, n.2, $2^{\circ}$ quadrimestre de 2021. Disponível em: www.univali.br/direitoepolitica - ISSN 1980-7791.

"sesmarias" should be revalidated ${ }^{35}$ and the possessions legitimated ${ }^{36}$. The need to create a agency- a person according to the law - was also determined to make the measurements and regularization ${ }^{37}$. It was also established that the right of the possessor could fall in commission, if they failed to proceed with the measurement within the stipulated deadlines, considering as vacant lands what was found uncultivated ${ }^{38}$.

Notwithstanding the stipulated deadlines for revalidation and legitimation of possessions, it was also determined that the Imperial State should proceed with the measurement of vacant lands ${ }^{39}$, extending it from the private domain ${ }^{40}$. The possessor should remove the land titles of property so that they can mortgage or dispose of their land, should they wish to do $\mathrm{so}^{41}$. However, to perform such a procedure, it was necessary to pay a certain amount to the Provincial Offices.

With the Circular of April 10, 1858, the Government was responsible for the expenses in the regularization process of small extension lands - of up to 250,000 $\mathrm{m}^{2}$ - belonging to those who could not afford the expenses required for the legitimation of possessions ${ }^{42}$.

To perform all of these actions, Decree no 1.318 , of January 30, 1854, which regulated the Land Law, provided for the creation of the General Division of Public Lands, subordinate to the Minister and Secretary of State for Business of the Empire $^{43}$, and of Special Offices of Public Lands, linked to existing Provinces ${ }^{44}$. It also established rules on measurement, revalidation, legitimation, sale and registration of land.

With regard specifically to registration of land, it was established that the Vicars of each of the Parishes of the Empire would be responsible for receiving the declarations of land made by the possessors themselves, imposing fines and penalties on those who failed to do within the deadlines stipulated by law or those who too did in an inaccurate way ${ }^{45}$. In this context, the first Brazilian property registry is born - the Registry of Vicary, also called Registries of Parish Land ${ }^{46}$.

\footnotetext{
35 Article $4^{\circ}$ of Law no 601 of September $18,1850$.

36 Article $5^{\circ}$ of Law no 601 of September 18, 1850.

37 Article 70 of Law no 601 of September 18, 1850.

38 Article $8^{\circ}$ of Law no 601 of September $18,1850$.

39 Article 90 of Law no 601 of September 18, 1850.

40 Article 10 of Law no 601 of September 18, 1850.

41 Article 11 of Law no 601 of September 18, 1850.

42 MOTTA, M. M. M. At the Frontiers of Power: land conflict and land rights in 19th century Brazil.

43 Article $1^{\circ}$ of Decree no 1.318 , of January 30, 1854.

44 Article $6^{\circ}$ of Decree no 1.318 , of January $30,1854$.

${ }^{45}$ Article 13 of Law no 601 of September 18, 1850 and article 97 of Decree no 1,318, of January 30, 1854.

46 MOTTA, M. M. M. At the Frontiers of Power: land conflict and land rights in 19th century Brazil.
} 
CAROLINO, Katia; STANZIOLA VIEIRA, Ricardo; SORRENTINO, Marcos. Land dilemmas in brazil: the history of land privatization in Brazil. Revista Eletrônica Direito e Política, Programa de Pós-Graduação Stricto Sensu em Ciência Jurídica da UNIVALI, Itajaí, v.16, n.2, $2^{\circ}$ quadrimestre de 2021. Disponível em: www.univali.br/direitoepolitica - ISSN 1980-7791.

Based on the reports presented by the Division of Public Lands, Motta ${ }^{47}$ demonstrates that, little by little, it became evident that the regularization policy instituted by the Land Law was a failure for several reasons. According to the author:

First, many of the landlords were not used to following a legal determination regarding the measurement and demarcation of their land. As we have already had the opportunity to follow, the more likely it was that these gentlemen would act as they had always done, that is, in breach of any rule that could limit their powers.

Second, any individual could be aware that the assumptions established by the Law of 1850 allowed all possessors regardless of the extent of their land - to register them. This procedure, in theory, would make it possible to legalize the occupation.

Third, the obligation to register a parcel of land was not accompanied by any documentary or testimonial evidence in relation to the area occupied. As we have also had occasion to show, the declarant should only inform the extent of his land, if it were known. The declarant was also requested to register the limits of his area. Strictly speaking, this was not asking a lot for a farmer, even though for a peasant, the registration could in fact guarantee dominance over the occupied land ${ }^{48}$.

In this context, Ligia Maria Osório Silva ${ }^{49}$ explains that, as it was implemented, the Land Law was unable to prevent large areas of vacant land from being appropriated illegally. According to the author ${ }^{50}$ :

The 1850 Law did not achieve one of its basic objectives, which was the demarcation of vacant lands, or, as it was said at the time, the discrimination of public and private lands, the first obstacle to be overcome in the implementation of a land policy. This occurred mainly for two reasons:

firstly, the regulation of the law left to the occupants of the land the initiative of the delimitation and demarcation process, and only after the private individuals informed the

\footnotetext{
47 MOTTA, M. M. M. At the Frontiers of Power: land conflict and land rights in 19th century Brazil 48 MOTTA, M. M. M. At the Frontiers of Power: land conflict and land rights in 19th century Brazil. p. 166-167.

49 SILVA, L. M. O. Agrarian Laws and the Unproductive Latifundio. São Paulo In Perspective, v. 11, n. 2, Sao Paulo, April - June 1997.

50 SILVA, L. M. O. Agrarian Laws and the Unproductive Latifundio. São Paulo In Perspective, v. 11, n. 2, Sao Paulo, April - June 1997. 17.
} 
CAROLINO, Katia; STANZIOLA VIEIRA, Ricardo; SORRENTINO, Marcos. Land dilemmas in brazil: the history of land privatization in Brazil. Revista Eletrônica Direito e Política, Programa de Pós-Graduação Stricto Sensu em Ciência Jurídica da UNIVALI, Itajaí, v.16, n.2, 20 quadrimestre de 2021. Disponível em: www.univali.br/direitoepolitica - ISSN 1980-7791.

State about of the limits of the land they occupied that they could deduce what had left to promote colonization;

second, the law was not clear enough in the prohibition of possession, because, although this was contained in article $1^{\circ}$, other articles led to the supposition that the "effective culture and habitual address" would guarantee the permanence of any possessor, at any time, in the occupied lands.

The combination of these two elements meant that the law served, in the period of its validity and until much later, to regularize the possession and not to stop it.

It is also worth noting that, by prohibiting the acquisition of vacant land for a title other than that of purchase ${ }^{51}$, the Land Law enshrined the "captivity of the land"52, since it prevented the possession of land by those that would replace the captive in the transition from slave to free labor ${ }^{53}$. According to José de Souza Martins:

Contrary to what happened in the American pioneer zones, the Land Law established in Brazil the captivity of the land here the lands were not and are not free, but captive.

Law 601 established, in absolute terms, that land would not be obtained by any means other than purchase. [...]. Concretely, the implementation of territorial legislation represented a victory for large farmers, since this was not the only social category to be concerned with the land issue.

On the other hand, there were those who advocated a free land regime that would give rise, in Brazil, to a middle class of free peasants that broke with the slave social structure and mischaracterized the farmers as slave masters and landlords to make them fundamentally bourgeois and businessmen.

The formula enshrined in the law, however, had its meaning in that historical circumstance. In the same year, 1850, the slave trade from Africa to Brazil ceased ${ }^{54}$.

\footnotetext{
51 Article $1^{0}$ of Law 601 of September 18, 1850.

52 MARTINS, J. de S. Expropriation and violence (The political issue in the field). São Paulo, Hucitec, 1980.

53 MOTTA, M. M. M. At the Frontiers of Power: land conflict and land rights in 19th century Brazil.

54 MARTINS, J. de S. Expropriation and violence (The political issue in the field). São Paulo, Hucitec, 1980. p. 73.
} 
CAROLINO, Katia; STANZIOLA VIEIRA, Ricardo; SORRENTINO, Marcos. Land dilemmas in brazil: the history of land privatization in Brazil. Revista Eletrônica Direito e Política, Programa de Pós-Graduação Stricto Sensu em Ciência Jurídica da UNIVALI, Itajaí, v.16, n.2, $2^{\circ}$ quadrimestre de 2021. Disponível em: www.univali.br/direitoepolitica - ISSN 1980-7791.

Thus, in determining that vacant lands could only be acquired through purchase, the Land Law provided the "legal basis for the transformation of land - which is a natural element and, therefore, has no value, from the point of view of the political economy - in merchandise, in a business object, therefore, having a price ${ }^{\prime 55}$. This measure made it impossible to access to land by slaves that would be freed in the future, preventing them from becoming peasants, because "having no property, they would not have the resources to "buy", pay for the land to the Crown", thus continuing at the mercy of the farmers as wage earners ${ }^{56}$.

With the promulgation of the second Federal Constitution, on February 24, 1891 marked historically by the proclamation of the Republic (in 1889), there was a decentralization of power, previously concentrated in the hands of the Emperor. The property of vacant land was transferred to the Member States, with only the portion of the territory indispensable for the defense of borders remaining under the Union's domain ${ }^{58}$.

The right to property remained fully guaranteed, except regarding expropriation for necessity or public utility, which, in turn, had to be carried out by means of prior indemnity ${ }^{59}$. In this legal context, each member state had to develop its own land policy, including creating and instituting legal mechanisms to measure, divide, demarcate, sell and register land, as well as legitimize possessions or other types of concessions that occurred in the past.

Subsequently, the first Brazilian Civil Code was issued, on January 1, $1916^{60}$ Federal Law no 3,071, of January 1, 1916 - inspired by the Napoleon Code ${ }^{61}$. This

\footnotetext{
55 STEDILE, J. P. The agrarian issue in Brazil. The traditional debate - 1500-1960. 2nd edition. Editora Expressão Popular, São Paulo, 2011. p. 22-23.

56 STEDILE, J. P. The agrarian issue in Brazil. The traditional debate - 1500-1960. 2nd edition.

Editora Expressão Popular, São Paulo, 2011. p. 23.

${ }^{57}$ BRASIL. Constitution of the Republic of the United States of Brazil (of February 24, 1891). Rio de Janeiro, RJ, 1891.

58 Article 64 of the Federal Constitution, on February 24, 1891.

${ }^{59}$ Article 72, § 17 of the Federal Constitution, on February 24, 1891.

60 The Civil Code of 1916 was revoked by Federal Law No. 10,406, of January 10, 2002, which instituted the new Civil Code. BRASIL. Federal Law No. 3,071, January 1, 1916. Civil Code of the United States of Brazil. Rio de Janeiro, RJ, 1916.

61 The protectionist conception of the right to property in the sense that the owner has the absolute, exclusive and almost unlimited right was consolidated in the Declaration of the Rights of Man and the Citizen of 1789 and, later, in the Napoleonic Code of 1804, inspiring the Civil Code of several countries in the world, including the first Civil Code of Brazil, promulgated in 1916. In article 17 of
} 
CAROLINO, Katia; STANZIOLA VIEIRA, Ricardo; SORRENTINO, Marcos. Land dilemmas in brazil: the history of land privatization in Brazil. Revista Eletrônica Direito e Política, Programa de Pós-Graduação Stricto Sensu em Ciência Jurídica da UNIVALI, Itajaí, v.16, n.2, 20 quadrimestre de 2021. Disponível em: www.univali.br/direitoepolitica - ISSN 1980-7791.

legal diploma - which was in force for 86 years (from 1916 to 2002) - guaranteed the owners of real estate "the right to use, enjoy and dispose of their property, and to recover them from the power of anyone who unjustly owns them"62, guaranteeing, therefore, the possibility, without any opposition, of having more real estate than what he can use himself ${ }^{63}$.

Following what had already been foreseen in the previous Federal Constitutions, the Civil Code established the hypotheses of expropriation for utility ${ }^{64}$ and public necessity ${ }^{65}$, imposing administrative limits on private property. This law also advanced, albeit in an extremely limited way, by providing for the usucapion institute - a term used in the feminine after the promulgation of the current Civil Code of 2002 - establishing that:

Article 550. That one that, for thirty years, without interruption or opposition, owns his property, will acquire his domain, regardless of title in good faith, which, in such a case, are presumed; being able to request the judge to declare it so by sentence, which will serve as a title for registration in the estate registry ${ }^{66}$.

Therefore, the conception given to the usucapion institute would make it possible to promote the distribution of land among those who hold the title to the property, but do not have possession ${ }^{67}$ (that is, the use), and those who hold possession, but do not have the title (of property). However, the conditions foreseen - that is, using the property without opposition and without interruption for at least 30 years

the Declaration of the Rights of Man and the Citizen it was established that "Since property is an inviolable and sacred right, nobody can be deprived of it, not when the legally proven public need requires it and on condition of just and prior indemnity" (DECLARATION OF THE RIGHTS OF MAN AND CITIZEN, 1789).

62 Article 524 of the 1916 Civil Code.

63 MELO, T. M. de. Law and concrete existence: the legal ideology and the social function of rural property. Master's Dissertation, Faculty of Law, University of São Paulo, São Paulo, 2007.

64 Article 179, item XXII, of the Brazilian Federal Constitution of 1824 and article 590, § 1 The following are considered cases of public need: I. The defense of the national territory. II. Public security. III. Public aid in cases of calamity. IV. Public health.

${ }^{65}$ Article 590, $\S 20$ Cases of public utility are considered: I. The foundation of settlements and public assistance, education or instruction establishments. II. The opening, widening or extension of streets, squares, canals, railways and in general, any public roads. III. The construction of works, or establishment, destined for the general good of a locality, its decoration and hygiene. IV. Mining.

66 BRASIL. Federal Law No. 3,071, January 1, 1916. Civil Code of the United States of Brazil. Rio de Janeiro, RJ, 1916.

67 According to article 485 of the Civil Code of 1916: "Everyone is considered to be a possessor, who in fact has the exercise, full or not, of any of the powers inherent in the domain, or property". 
CAROLINO, Katia; STANZIOLA VIEIRA, Ricardo; SORRENTINO, Marcos. Land dilemmas in brazil: the history of land privatization in Brazil. Revista Eletrônica Direito e Política, Programa de Pós-Graduação Stricto Sensu em Ciência Jurídica da UNIVALI, Itajaí, v.16, n.2, $2^{\circ}$ quadrimestre de 2021. Disponível em: www.univali.br/direitoepolitica - ISSN 1980-7791.

- prove to be unfeasible to guarantee any proposal for the distribution of land. In addition, the change of possessor to owner through the usucapion institute should be done through a judicial process, representing, therefore, one more difficulty especially for the possessor without material resources and without knowledge about the procedures of justice.

Later, the usucapion institute was foreseen in the 1934 Magna Carta68, promulgated in the 1930 Revolution, which, when creating the "pro labore" usucapion, established new conditions, as follows:

Article 125 - Every Brazilian who, not being a rural or urban owner, occupies, for ten continuous years, without opposition or recognition of another's domain, a piece of land of up to ten hectares, making him productive on reason of his work and having his home there, will acquire the domain of the soil, through a declaratory sentence duly transcribed ${ }^{69}$.

In this legal context, it is observed that, in addition to the occupation of land with up to ten hectares for ten years without opposition, the usucapion demanded from the possessor the productive work and use for housing, while the owners, for the first time, established the right to property would be guaranteed if it were not exercised against social or collective interest, in the form that the law determines $^{70}$. It is, therefore, the first legal measure to consolidate what in the Federal Constitution of 1988 came to call "the socio-environmental function of property".

However, in the following Constitution, that of 1937 , which had as its historical landmark the dictatorship of Getulio Vargas, there was another regression. The terms "social or collective interest" were removed from the constitutional text,

\footnotetext{
${ }^{68}$ BRASIL. Constitution of the Republic of the United States of Brazil (from July 16, 1934). Rio de Janeiro, RJ, 1934.

69 BRASIL. Constitution of the Republic of the United States of Brazil (from July 16, 1934). Rio de Janeiro, RJ, 1934

70 Article 113, item 17, of the Federal Constitution of 1934.
} 
CAROLINO, Katia; STANZIOLA VIEIRA, Ricardo; SORRENTINO, Marcos. Land dilemmas in brazil: the history of land privatization in Brazil. Revista Eletrônica Direito e Política, Programa de Pós-Graduação Stricto Sensu em Ciência Jurídica da UNIVALI, Itajaí, v.16, n.2, $2^{\circ}$ quadrimestre de 2021. Disponível em: www.univali.br/direitoepolitica - ISSN 1980-7791.

maintaining the expropriation for necessity or public utility through prior indemnity ${ }^{71}$ and usucapion "pro labore"72.

With the 1946 Federal Constitution, which preceded the 1964 military coup, there was a new advance in relation to the use of property by conditioning it to social welfare, with the objective of promoting a fair distribution of property with equal opportunity for all73. The "social interest" expropriation modality to be paid by means of a prior and fair indemnity in cash was incorporated to the institute of expropriation about utility and need public ${ }^{74}$. Therefore, this new type of expropriation allowed the Executive Branch to remove the property of a private individual and transfer it to the domain of a group of people or certain recipients specified in the law, with a view to reducing social inequalities.

However, according to some authors ${ }^{75}$, although the constitutional text has advanced in the sense of providing the necessary legal support for the realization of a fair and equitable distribution of land in Brazil through expropriation for social interest, by establishing that the indemnity should be previously made in cash, the constitutional text made the application of the legal provision unfeasible.

According to Vieira ${ }^{76}$, the conclusion at the time was that agrarian reform would only be possible if the constitutional provision was changed, since the State was not in a position to afford such expenses. In the same sense, Ligia Maria Osório Silva77 explains that "the approved terms constituted an obstacle during the entire period following the social forces that fought fervently for the alteration of the

\footnotetext{
${ }^{71}$ Article 122, item 14 of the 1937 Federal Constitution.

72 In the following Constitution, that of 1937 , an identical text was reproduced in article 148. BRASIL. Constitution of the Republic of the United States of Brazil (from November 10, 1937). Rio de Janeiro, RJ, 1937.

73 Article 147 of the 1946 Federal Constitution.

74 Article 141, $\S 16$, of the 1946 Federal Constitution. BRASIL. Constitution of the Republic of the United States of Brazil (September 18, 1946). Rio de Janeiro, RJ, 1946.

75 VIEIRA, J. C. Constitutional aspects of Agrarian Law - Constitutional Amendment no 10/64, Semina: Cultural and Scientific Magazine of the State University of Londrina, v. 9, n. 1, Londrina, September 1988; SILVA, L. M. O. Agrarian Laws and the Unproductive Latifundio. São Paulo In Perspective, v. 11, n. 2, Sao Paulo, April - June 1997.

76 VIEIRA, J. C. Constitutional aspects of Agrarian Law - Constitutional Amendment no 10/64, Semina: Cultural and Scientific Magazine of the State University of Londrina, v. 9, n. 1, Londrina, September 1988.

77 SILVA, L. M. O. Agrarian Laws and the Unproductive Latifundio. São Paulo In Perspective, v. 11, n. 2, Sao Paulo, April - June 1997. p. 19.
} 
CAROLINO, Katia; STANZIOLA VIEIRA, Ricardo; SORRENTINO, Marcos. Land dilemmas in brazil: the history of land privatization in Brazil. Revista Eletrônica Direito e Política, Programa de Pós-Graduação Stricto Sensu em Ciência Jurídica da UNIVALI, Itajaí, v.16, n.2, $2^{\circ}$ quadrimestre de 2021. Disponível em: www.univali.br/direitoepolitica - ISSN 1980-7791.

agrarian structure and for the fight against the unproductive property of land", once that the previous indemnity and in cash made the expropriations unfeasible.

Although in the legal sphere, the theme was paralyzed, since the expropriation for social interest needs a regulatory law that took 16 years to be approved in the following decades (1950 to 1960), the theme of agrarian reform gained a new projection. Various mobilizations of rural workers around the struggle, not only for the right to land, but also for guaranteeing labor rights for rural workers, began to receive greater attention ${ }^{78}$.

The law that defined the cases of expropriation for social interest and provided for its application was then approved - Federal Law no 4,132, of September 10, $1962^{79}$ - considering the following situations provided for in article 2 as social interest:

I - the use of all unproductive or exploited property without correspondence with the needs of housing, work and consumption of the population centers to which it must or can supply by its economic destiny.

II - VETOED.

III - the establishment and maintenance of colonies or colonization cooperatives and agricultural work:

IV - the maintenance of possessor on urban land where, with the express or tacit tolerance of the owner, they have built their qualification, forming residential nuclei of more than 10 (ten) families.

$\mathrm{V}$ - the construction of popular houses.

VI - lands and waters susceptible to extraordinary appreciation, due to the completion of public works and services, notably sanitation, ports, transport, electrification, water storage and irrigation, in the event that socially exploited areas are not said.

VII - the protection of the soil and the preservation of water courses and sources and forest reserves.

\footnotetext{
78 MEDEIROS, L. S. de; QUINTANS, M. T. D.; ZIMMERMANN, S. A. Rural and urban in Brazil: legal frameworks and political strategies. Contemporânea - Sociology Journal of UFSCar, v. 4, n. 1, São Carlos, January - June 2014.

${ }^{79}$ BRASIL. Federal Law no 4,132, September 10, 1962. Defines cases of expropriation for social interest and provides for its application. Brasília, DF, 1962.
} 
CAROLINO, Katia; STANZIOLA VIEIRA, Ricardo; SORRENTINO, Marcos. Land dilemmas in brazil: the history of land privatization in Brazil. Revista Eletrônica Direito e Política, Programa de Pós-Graduação Stricto Sensu em Ciência Jurídica da UNIVALI, Itajaí, v.16, n.2, $2^{\circ}$ quadrimestre de 2021. Disponível em: www.univali.br/direitoepolitica - ISSN 1980-7791.

VIII - the use of areas, places or property that, due to their characteristics, are appropriate for the development of tourist activities. Included by Law no 6,513, of December 20, $2007^{80}$.

Among the situations, the concern with the use of the property for the purposes of production and supply of the population stands out, and the need to supply housing shortages, although in the urban area the condition of express or tacit tolerance of the owner has been imposed, which demonstrates new setback in the maintenance of private property to the detriment of the consolidation of collective uses, in this case, explicitly related to the formation of residential nuclei in an urban area.

With the military coup on April 1, 1964, although there is consensus on the setback in terms of guaranteeing rights in other sectors, regarding agrarian reform, the first post-64 military government was successful where several previous governments failed.

With the publication of Constitutional Amendment no 10, of November 9, 1964, article $147, \S 10$ was included in the Federal Constitution of $1967^{81}$, allowing the payment of indemnities related to expropriation for social interest to be, from then on, were made in public debt securities (and no longer in cash, as predicted earlier), displeasing owners who obviously did not wish to receive government bonds as payment of indemnities.

Article $147 . \S 1^{\circ}$. For the purposes provided for in this article, the Union may promote expropriation of rural territorial property, upon payment of the prior and fair indemnity in special public debt securities, with an exact monetary correction clause, according to indices set by the National Council of Economy, redeemable within a maximum period of twenty years, in successive annual installments, ensuring its acceptance at any time, as a means of payment of up to fifty percent of the Rural Territorial Tax and as payment of the price of public lands ${ }^{82}$.

80 BRASIL. Federal Law no 4,132, September 10, 1962. Defines cases of expropriation for social interest and provides for its application. Brasília, DF, 1962.

81 BRASIL. 1967 Constitution of the Federative Republic of Brazil. Brasília, DF, 1967.

82 BRASIL. 1967 Constitution of the Federative Republic of Brazil. Brasília, DF, 1967. 
CAROLINO, Katia; STANZIOLA VIEIRA, Ricardo; SORRENTINO, Marcos. Land dilemmas in brazil: the history of land privatization in Brazil. Revista Eletrônica Direito e Política, Programa de Pós-Graduação Stricto Sensu em Ciência Jurídica da UNIVALI, Itajaí, v.16, n.2, $2^{\circ}$ quadrimestre de 2021. Disponível em: www.univali.br/direitoepolitica - ISSN 1980-7791.

Another measure adopted by the military government was the promulgation of the Land Statute - Federal Law no 4.504, of November 30, 1964. Through this legal instrument, two important goals were established: the execution of agrarian reform, defined as "the set of measures which aims to promote a better distribution of the land, through changes in the regime of its possession and use, in order to comply with the principles of social justice and the increase of productivity" 83 and the promotion of the agricultural policy defined as "the set of measures of support to the land, which are intended to guide, in the interests of the rural economy, agricultural activities, whether in the sense of guaranteeing full employment for them, or in harmonizing them with the country's industrialization process" ${ }^{84}$.

With regard to the agrarian issue, this legal diploma established that the opportunity of access to land ownership should be ensured to everyone, conditioned by their social function, in the manner provided for in this law ${ }^{85}$. By this legal instrument, it was determined that the land ownership fulfill its social function when, at the same time ${ }^{86}$ :

a) it favors the well-being of the owners and workers who work there, as well as their families.

b) maintains satisfactory levels of productivity.

c) ensures the conservation of natural resources.

d) observes the legal provisions that regulate fair working relationships between those who own and cultivate it.

It is observed that the conception of the social function of the property was associated with three criteria, namely: 1) the environmental - when establishing the need to conserve natural resources; 2) social and labor - when establishing the need for well-being and fair work relationships; and, finally, 3) the productive - by predicting the need to maintain satisfactory levels of productivity. Although other conditions were created that directly interfered with the concept of the social

\footnotetext{
83 Article $10, \S 10$ of Federal Law no 4.504, of November 30, 1964.

${ }^{84}$ Article $1^{\circ}$, $\S 2^{\circ}$ of Federal Law no 4.504, of November 30, 1964.

${ }^{85}$ Article $2^{\circ}$ of Federal Law no 4.504, of November 30, 1964.

${ }^{86}$ Article $2^{\circ}, \S 1^{\circ}$ of Federal Law n 4.504, of November 30, 1964.
} 
CAROLINO, Katia; STANZIOLA VIEIRA, Ricardo; SORRENTINO, Marcos. Land dilemmas in brazil: the history of land privatization in Brazil. Revista Eletrônica Direito e Política, Programa de Pós-Graduação Stricto Sensu em Ciência Jurídica da UNIVALI, Itajaí, v.16, n.2, $2^{\circ}$ quadrimestre de 2021. Disponível em: www.univali.br/direitoepolitica - ISSN 1980-7791.

function of property, the criteria mentioned above were maintained in the current Federal Constitution ${ }^{87}$.

The Land Statute also established and classified rural properties into land property, small property, family properties and rural companies. However, although the terms provided for in the Land Statute have been used for 24 years (from 1964 to 1988), consolidating a rich literature on the subject, with the promulgation of the current Federal Constitution (of 1988) ${ }^{88}$, a new nomenclature was established, revoking the concepts foreseen in the Land Statute.

With the promulgation of the sixth Federal Constitution of 1967, the social function of property was envisaged as one of the principles of the economic order ${ }^{89}$ and again the payment of expropriation for social interest was reestablished through prior and fair compensation in cash ${ }^{90}$. With the Institutional Act no 9 of 1969, this article was reformulated, in such a way that the compensation for the expropriation of the rural territorial property returned to be made through the payment of a fair indemnity, but no longer in a prior form, in special public debt securities, redeemable within a maximum period of twenty years, in successive annual installments ${ }^{91}$.

Two years after the end of the dictatorship, on February 1, 1987, a new National Constituent Assembly was installed, with the purpose of drafting a new Federal Constitution, which, in turn, was promulgated on October 5, 1988. In this Constituent Assembly, the theme of the social function of property put openly the interest of owners and social movements ${ }^{92}$.

\footnotetext{
87 BRASIL. 1988 Constitution of the Federative Republic of Brazil. Brasília, DF, 1988.

88 BRASIL. 1988 Constitution of the Federative Republic of Brazil. Brasília, DF, 1988.

89 Article 157 of the 1967 Federal Constitution.

90 Article 150, § 22 of the 1967 Federal Constitution. BRASIL. 1967 Constitution of the Federative Republic of Brazil. Brasília, DF, 1967.

91 Article 157, § $1^{\circ}$ of the 1969 Federal Constitution. BRASIL. Institutional Act No. 9, of April 25, 1969. Brasília, DF, 1969.

92 TALASKA, A. The Brazilian agrarian space from a conceptual perspective: from legal aspects to territorial implications. Thesis (Doctorate in Regional Development) - University of Santa Cruz do Sul, Santa Cruz do Sul, 2015; MEDEIROS, L. S. de; QUINTANS, M. T. D.; ZIMMERMANN, S. A. Rural and urban in Brazil: legal frameworks and political strategies. Contemporânea - Sociology Journal of UFSCar, v. 4, n. 1, São Carlos, January - June 2014.
} 
CAROLINO, Katia; STANZIOLA VIEIRA, Ricardo; SORRENTINO, Marcos. Land dilemmas in brazil: the history of land privatization in Brazil. Revista Eletrônica Direito e Política, Programa de Pós-Graduação Stricto Sensu em Ciência Jurídica da UNIVALI, Itajaí, v.16, n.2, $2^{\circ}$ quadrimestre de 2021. Disponível em: www.univali.br/direitoepolitica - ISSN 1980-7791.

As a result, in the final text of the 1988 Federal Constitution, the right to property, the social function of property and the right to expropriation for social interest were recognized as fundamental rights ${ }^{93}$. A specific chapter was created to deal with the theme - Chapter III - Agricultural and Land Policy and Agrarian Reform present in Title VII - Economic and Financial Order, composed of articles 184 to 191 that establish norms for both agrarian issues, as for agricultural issues.

Following what had already been provided for in the Land Statute, it was established that rural property fulfills its social function when it meets, simultaneously, according to criteria and degrees of demand established by law, the following requirements: "I - rational and adequate use; II - adequate use of available natural resources and preservation of the environment; III - observance of the provisions that regulate labor relations; IV - exploitation that favors the well-being of owners and workers"94.

Interpreted in accordance with article 225 of the Federal Constitution ${ }^{95}$, it is observed that property, in addition to a social function, also has an environmental function, since the duty of environmental preservation is imposed on public authorities and the community. In this legal context, the term "social function" has been replaced by "socio-environmental function", whose non-compliance, under the terms of the law, should lead to expropriation for social interest for the purposes of agrarian reform:

Article 184. It is incumbent upon the Union to expropriate for social interest, for agrarian reform purposes, rural property that is not fulfilling its social function, through prior and fair indemnity in agrarian debt securities, with a clause for the preservation of real value, redeemable at up to twenty years, from the second year of its issue, and whose use will be defined by law. ${ }^{96}$

\footnotetext{
93 Article 50, item XXII, item XXIII and item XXIV. BRASIL. 1988 Constitution of the Federative Republic of Brazil. Brasília, DF, 1988.

94 Article 186 of the 1988 Federal Constitution.

${ }^{95}$ Article 225 of the Federal Constitution says that "everyone has the right to an ecologically balanced environment, a good for the common use of the people and essential to a healthy quality of life, imposing on the Public Power and the community the duty to defend and preserve it for present and future generations".

96 BRASIL. 1988 Constitution of the Federative Republic of Brazil. Brasília, DF, 1988.
} 
CAROLINO, Katia; STANZIOLA VIEIRA, Ricardo; SORRENTINO, Marcos. Land dilemmas in brazil: the history of land privatization in Brazil. Revista Eletrônica Direito e Política, Programa de Pós-Graduação Stricto Sensu em Ciência Jurídica da UNIVALI, Itajaí, v.16, n.2, $2^{\circ}$ quadrimestre de 2021. Disponível em: www.univali.br/direitoepolitica - ISSN 1980-7791.

In the legal world, this constitutional provision provides the legal support for carrying out a wide and necessary agrarian reform. However, as Professor Carla Amado Gomes explains, this is a falsely broad norm, since the following article excludes the possibility of expropriation of the productive properties, as follows:

Article 185. Expropriation for agrarian reform purposes is not susceptible:

I - the small and medium-sized rural property, as defined by law, provided that its owner does not have another.

II - productive property ${ }^{97}$.

The exceptions provided for in item II, of article 185, lead to the understanding that, regardless of size, productive rural property should not be the object of expropriation for social interest even if it does not meet the other criteria of the social function - the environment and the socio-labor. However, it is worth noting that the wording of the final part of the sole paragraph of article 185 - which was submitted for approval by the National Constituent Assembly - allowed the expropriation of productive property if the requirements related to the social function were not observed ${ }^{98}$. However, the decision of the Constituents, at that time, was to supply the part of the text that allowed the expropriation of the productive property, as follows:

Sole paragraph - The law will guarantee special treatment to productive property and will establish rules for the fulfillment of the requirements related to its social function (whose noncompliance will allow its expropriation, pursuant to article 184).

For José Gomes da Silva99, as the constitutional text was approved, "it is, in fact, one of the most serious setbacks ever occurred in the history of the Brazilian Constitutions", since by excluding the productive properties of the list of

\footnotetext{
97 BRASIL. 1988 Constitution of the Federative Republic of Brazil. Brasilia, DF, 1988.

98 According to Alcione Talaska, the final wording of the final text was the result of the dispute between conservatives and pro-reformists, in which the former emphasized that productive property should not be expropriated, while the latter associated the right property to its social function, including the expropriation of the country estate. TALASKA, A. The Brazilian agrarian space from a conceptual perspective: from legal aspects to territorial implications. Thesis (Doctorate in Regional Development) - University of Santa Cruz do Sul, Santa Cruz do Sul, 2015

${ }_{99}$ SILVA, J. G. da. Agrarian reform in Brazil. STEDILE, João Pedro (org.). The agrarian issue in Brazil: the debate in the 1990s. Editora Expressão Popular, 1st edition, São Paulo, 2013.
} 
CAROLINO, Katia; STANZIOLA VIEIRA, Ricardo; SORRENTINO, Marcos. Land dilemmas in brazil: the history of land privatization in Brazil. Revista Eletrônica Direito e Política, Programa de Pós-Graduação Stricto Sensu em Ciência Jurídica da UNIVALI, Itajaí, v.16, n.2, $2^{\circ}$ quadrimestre de 2021. Disponível em: www.univali.br/direitoepolitica - ISSN 1980-7791.

expropriation for the purposes of agrarian reform, the Federal Constitution of 1988 made, in practice, no serious attempt to change the Brazilian land structure.

For Ligia Maria Osório Silva100:

It can be concluded that the concept of the social function of the land, although it was introduced to facilitate large-scale expropriations of unproductive latifundios, served to distract attention from the injustices inherent in a very unequal distribution of agrarian resources, placing the emphasis in the land uses, which is less compromising.

In this context, the only criterion used in expropriation for social interest for the purpose of agrarian reform has been the criterion of unproductiveness. Therefore, large tracts of land that, disregarding social, labor and environmental issues, since they are considered productive, are not subjected to expropriation for social interest, maintaining the same status quo as before, namely: the guarantee of private interests, represented by property private, to the detriment of social interest, represented by the fair and equitable distribution of land to produce healthy food and fair labor relations in the countryside.

Allied to this, when determining the elaboration of a complementary law to establish the special contradictory procedure, of summary rite, for the judicial process of expropriation ${ }^{101}$, the Federal Constitution inserted the possibility of the Judiciary to interfere in issues related to the legality of expropriations, arbitration of values by way of indemnity, etc. as a result of the expropriation lawsuit ${ }^{102}$.

In relation to the legal institute of usucapion, there is a reduction from 10 to 5 years and an increase from 10 to 50 hectares, as follows:

Article 191. Anyone who, without being the owner of a rural or urban property, has as his, for five uninterrupted years, without opposition, an area of land, in a rural area, not exceeding fifty hectares, making it productive for his work or of his family, having his dwelling, will acquire the property.

100 SILVA, L. M. O. Agrarian Laws and the Unproductive Latifundio. São Paulo In Perspective, v. 11, n. 2, Sao Paulo, April - June 1997. p. 25.

101 Article $184, \S 30$ of the 1988 Federal Constitution.

102 MEDEIROS, L. S. de; QUINTANS, M. T. D.; ZIMMERMANN, S. A. Rural and urban in Brazil: legal frameworks and political strategies. Contemporânea - Sociology Journal of UFSCar, v. 4, n. 1, São Carlos, January - June 2014. 
CAROLINO, Katia; STANZIOLA VIEIRA, Ricardo; SORRENTINO, Marcos. Land dilemmas in brazil: the history of land privatization in Brazil. Revista Eletrônica Direito e Política, Programa de Pós-Graduação Stricto Sensu em Ciência Jurídica da UNIVALI, Itajaí, v.16, n.2, $2^{\circ}$ quadrimestre de 2021. Disponível em: www.univali.br/direitoepolitica - ISSN 1980-7791.

Single paragraph. Public real estate shall not be acquired by usucapion.

In 2014, as a result of Constitutional Amendment no 81, the expropriation of urban or rural properties was allowed, for purposes of agrarian reform or popular housing program, where psychotropic plant culture and slave labor could be found, without the payment of any indemnity to the owner, demonstrating an advance, at least in legislative terms, in the prohibition of slave labor in Brazil.

The terms - small property and large property- have been replaced by the terms small and medium-sized rural and productive property. Through Federal Law no 8,629 , of February $25,1993^{103}$, small and medium-sized properties, respectively, were defined as properties with an area between 1 and 4 fiscal modules and greater than 4 and up to 15 fiscal modules ${ }^{104}$, while the large property, as it does not have an express definition in the law, by deduction, was defined as the property with an area above 15 fiscal modules.

In relation to productive property, the law defined it as "that which, exploited economically and rationally, reaches, simultaneously, degrees of land use and efficiency in exploration, according to indexes fixed by the competent federal agency"105, being that the degree of land use should be at least $80 \%$ and the degree of efficiency in exploration at least $100 \%{ }^{106}$. Regarding unproductive property, by exclusion, it is defined as that which does not reach the production and productivity indices established by law, regardless of size - small, medium or large property.

In 2003, with the publication of the II National Plan for Agrarian Reform ${ }^{107}$, the expectations that, at last, the long-awaited agrarian reform would be carried out, which would change the course of the Brazilian land structure. However, as well explained by Nakatani, Faleiros and Vargas ${ }^{108}$, the option seems to have been to freeze the land structure with compensation policies, such as: the Family Agriculture Strengthening Program (better known as PRONAF); the "Technical Assistance and Rural Extension (better known as ATER) and the "Bolsa Família", which also covered part of the rural population.

103 Federal Law no 8,629, of February 25, 1993, provides for the regulation of constitutional provisions related to agrarian reform, provided for in Chapter III, Title VII, of the Federal Constitution.

104 Article $4^{\circ}$ of Federal Law no 8,629, of February 25, 1993.

105 Article 60 of Federal Law no 8,629, of February 25, 1993.

106 Article 60, $\S 1^{\circ}$ and $\S 2^{\circ}$ of Federal Law no 8,629, of February 25, 1993.

107 The I National Plan for Agrarian Reform (I PNRA) was published in 1985 at the beginning of the Sarney government.

108 NAKATANI, P.; FALEIROS, R. N.; VARGAS, N. C. History and the limits of agrarian reform in Brazilian contemporaneity. Serv. Soc. Soc., n. 110, São Paulo, April / June 2012. 
CAROLINO, Katia; STANZIOLA VIEIRA, Ricardo; SORRENTINO, Marcos. Land dilemmas in brazil: the history of land privatization in Brazil. Revista Eletrônica Direito e Política, Programa de Pós-Graduação Stricto Sensu em Ciência Jurídica da UNIVALI, Itajaí, v.16, n.2, $2^{\circ}$ quadrimestre de 2021. Disponível em: www.univali.br/direitoepolitica - ISSN 1980-7791.

Undoubtedly, these public policies contribute to improving the situation of many families living in the rural area, however they do not solve the social and environmental problem currently experienced by the Brazilian population, in such a way that it becomes necessary to create new public policies for access to land that allow to break with historical paradigms of land concentration in the hands of a few, while many do not even have a piece of land to grow their food.

\section{FINAL CONSIDERATIONS}

From what was exposed in this article, we show that the individualistic approach of liberalism, reflected in the private ownership of the land, made it impossible a fair and equitable distribution of land in Brazil despite the constant social demands that still occur today. In this way, even though there are legal instruments capable of altering the unequal relations that exist in Brazilian society, the superiority of the private interest, based on the liberal tradition of Law, precludes any social interpretation of legal norms.

The concentration of land remains a persistent historical data in Brazil, demonstrating that the different legal strategies adopted were not sufficient to correct the injustices of access to land since the times of colonization, corroborating the hypothesis that simple normative forecasting does not change the world of facts and often serves to maintain the status quo, that is, the maintenance of the private interest to the detriment of the social interest.

\section{BIBLIOGRAPHIC REFERENCES}

BRASIL. License of October 5, 1795, Rio de Janeiro, RJ, 1795.

BRASIL. Institutional Act No. 9, of April 25, 1969. Brasília, DF, 1969.

BRASIL. Constitution of the Republic of the United States of Brazil (of February 24, 1891). Rio de Janeiro, RJ, 1891.

BRASIL. Constitution of the Republic of the United States of Brazil (from July 16, 1934). Rio de Janeiro, RJ, 1934.

BRASIL. Constitution of the Republic of the United States of Brazil (from November 10, 1937). Rio de Janeiro, RJ, 1937.

BRASIL. Constitution of the Republic of the United States of Brazil (September 18, 1946). Rio de Janeiro, RJ, 1946. 
CAROLINO, Katia; STANZIOLA VIEIRA, Ricardo; SORRENTINO, Marcos. Land dilemmas in brazil: the history of land privatization in Brazil. Revista Eletrônica Direito e Política, Programa de Pós-Graduação Stricto Sensu em Ciência Jurídica da UNIVALI, Itajaí, v.16, n.2, $2^{\circ}$ quadrimestre de 2021. Disponível em: www.univali.br/direitoepolitica - ISSN 1980-7791.

BRASIL. 1967 Constitution of the Federative Republic of Brazil. Brasília, DF, 1967.

BRASIL. 1988 Constitution of the Federative Republic of Brazil. Brasília, DF, 1988.

BRASIL. Political Constitution of the Empire of Brazil (March 25, 1824). Rio de Janeiro, RJ, 1824.

BRASIL. Decree no 1.318 , of January 30, 1854. It orders to execute Law no 601, of September 18, 1850. Rio de Janeiro, RJ, 1854.

BRASIL. Law no 601, September 18, 1850. Provides for the vacant lands of the Empire. Rio de Janeiro, RJ,1850.

BRASIL. Federal Law No. 3,071, January 1, 1916. Civil Code of the United States of Brazil. Rio de Janeiro, RJ, 1916.

BRASIL. Federal Law no 4,132, September 10, 1962. Defines cases of expropriation for social interest and provides for its application. Brasília, DF, 1962.

BRASIL. Federal Law no 8,629, February 25, 1993. Provides for the regulation of constitutional provisions related to agrarian reform, provided for in Chapter III, Title VII, of the Federal Constitution. Brasília, DF, 1993.

DEBONI, G. Private property: from absolute character to social and environmental function. Magazine of the Faculty of Law Dom Alberto, v. 1, 2010.

DECLARATION OF HUMAN AND CITIZEN'S RIGHTS, 1789. University of São Paulo: Virtual Human Rights Library, 2015.

LIMA, R. C. Small territorial history of Brazil: "sesmarias" and vacant lands. Imprenta, Porto Alegre, Sulina, 1954.

MARTINS, J. de S. Expropriation and violence (The political issue in the field). São Paulo, Hucitec, 1980.

MEDEIROS, L. S. de; QUINTANS, M. T. D.; ZIMMERMANN, S. A. Rural and urban in Brazil: legal frameworks and political strategies. Contemporânea - Sociology Journal of UFSCar, v. 4, n. 1, São Carlos, January - June 2014.

MELO, T. M. de. Law and concrete existence: the legal ideology and the social function of rural property. Master's Dissertation, Faculty of Law, University of São Paulo, São Paulo, 2007. 
CAROLINO, Katia; STANZIOLA VIEIRA, Ricardo; SORRENTINO, Marcos. Land dilemmas in brazil: the history of land privatization in Brazil. Revista Eletrônica Direito e Política, Programa de Pós-Graduação Stricto Sensu em Ciência Jurídica da UNIVALI, Itajaí, v.16, n.2, $2^{\circ}$ quadrimestre de 2021. Disponível em: www.univali.br/direitoepolitica - ISSN 1980-7791.

MOTTA, M. M. M. At the Frontiers of Power: land conflict and land rights in 19th century Brazil. Public Archives of the State of Rio de Janeiro, Rio de Janeiro, 1998.

NAKATANI, P.; FALEIROS, R. N.; VARGAS, N. C. History and the limits of agrarian reform in Brazilian contemporaneity. Serv. Soc. Soc., n. 110, São Paulo, April / June 2012.

OLIVEIRA, M. M. de. How to do qualitative research. Publisher Vozes, Petrópolis, 2007.

STEDILE, J. P. The agrarian issue in Brazil. The traditional debate - 1500-1960. 2nd edition. Editora Expressão Popular, São Paulo, 2011.

TALASKA, A. The Brazilian agrarian space from a conceptual perspective: from legal aspects to territorial implications. Thesis (Doctorate in Regional Development) - University of Santa Cruz do Sul, Santa Cruz do Sul, 2015.

SILVA, J. G. da. Agrarian reform in Brazil. STEDILE, João Pedro (org.). The agrarian issue in Brazil: the debate in the 1990s. Editora Expressão Popular, 1st edition, São Paulo, 2013.

SILVA, L. M. O.; SECRETO, M. V. Public lands, private occupation: elements for the comparative history of territorial appropriation in Argentina and Brazil. Economy and Society, v. 8 n. 1, Campinas, December 1999.

SILVA, L. M. O. Devoluted Lands and Latifundio. Effects of the 1850 law. Editora da Unicamp. Campinas, 1996;

SILVA, L. M. O. Agrarian Laws and the Unproductive Latifundio. São Paulo In Perspective, v. 11, n. 2, Sao Paulo, April - June 1997.

VIEIRA, J. C. Constitutional aspects of Agrarian Law - Constitutional Amendment no 10/64, Semina: Cultural and Scientific Magazine of the State University of Londrina, v. 9, n. 1, Londrina, September 1988.

RECEBIDO EM: OUT/2020

APROVADO EM: MAR/2021 